\title{
PROBLEMATIC ASPECTS OF THE CONSUMER PROTECTION ACT 28 OF 2008 IN RELATION TO PROPERTY TRANSACTIONS: LINKED TRANSACTIONS, FIXED-TERM CONTRACTS AND UNSIGNED SALE AGREEMENTS
}

\author{
Henk Delport
}

$B A \quad L L B \quad L L D$

Professor, Faculty of Law

Nelson Mandela Metropolitan University

Port Elizabeth

\section{SUMMARY}

The article examines whether and to what extent sections 13(1), 14 and 50(2)(a) of the Consumer Protection Act 68 of 2008 apply to transactions relating to immovable property. Section 13(1) concerns linked agreements (also known as "tying arrangements"), section 14 deals with fixed-term contracts while section 50 (2)(a) relates to unsigned written agreements. It is submitted that section 13(1) applies to plot-and-plan transactions entered into by property developers, as well as leases of immovable property where the lessee is obligated to enter into agreements with third parties such as security companies or garden-maintenance services. There is considerable confusion in the property industry whether section 14 applies to estate agency sole mandates and leases of immovable property where one or both parties are a natural person. The author submits that on a purposive interpretation of section 14 neither of these agreements is governed by the provision. Section 50(2)(a) conveys that when a consumer agreement is in writing either by reason of the provisions of the Act or voluntarily, the agreement is binding and enforceable whether or not the consumer signed the agreement. It is submitted that the provision does not apply to agreements of sale governed by the Alienation of Land Act 68 of 1981, the Share Blocks Control Act 59 of 1980, the Property Time-sharing Control Act 75 of 1983 and the Housing Development Schemes for Retired Persons Act 65 of 1988.

\section{INTRODUCTION}

Judging by its get-up the Consumer Protection Act 68 of 2008 ("the Act") is a formidable statute, comprising 122 main sections grouped into seven chapters, countless subsections, two schedules, and all the regulations and 
notices published under the Act. ${ }^{1}$ It repeals five other statutes, a number of sections of a sixth, ${ }^{2}$ and introduces amendments to three existing Acts. ${ }^{3}$ Its purpose, set out in section 3(1), is spread over 14 subsections and subparagraphs. Interpreting the Act requires a consideration of foreign and international law, and of international conventions, declarations or protocols relating to consumer protection. ${ }^{4}$ Common law, too, is not entirely forgotten, in that it is expressly provided that no provision of the Act is to be interpreted so as to preclude a consumer from exercising any right afforded under common law. ${ }^{5}$ That the Act must be taken seriously is made clear in chapter 6 , entitled "Enforcement of Act". A contravention of certain provisions constitutes an offence, ${ }^{6}$ while a disregard for conduct required (or prohibited) under the Act invites the imposition of an administrative fine up to $10 \%$ of the wrongdoer's annual turnover or R1 million, whichever is the greater.

Disappointingly, the Act is less impressive substantively. Scholarly research publications - one after the other - have exposed fundamental flaws in the Act, bad drafting, obvious mistakes, ignorance of the common law and the haphazard importation of concepts developed under foreign law. ${ }^{8}$ A respected academic has gone as far as describing the legislation as one of the most irritating Acts he has ever read. ${ }^{9}$ While not everyone may necessarily agree with this rating - the Act faces tough competition on that front - no one will deny that it constitutes a challenging task to come to grips with even some basic concepts embodied in the Act. Ironically, section 22 confers on consumers a right to information in plain and understandable language, yet the Act itself fails to meet that benchmark in many respects. The wisdom of Einstein comes to mind:

"Any intelligent fool can make things bigger, more complex, and more violent. It takes a touch of genius - and a lot of courage - to move in the opposite direction".

See the definition of "this Act" in $\mathrm{s} 1$.

S 121(1).

Schedule 1.

$\mathrm{S} 2(2)(\mathrm{a})$ and (b).

$S 2(10)$.

See s $107-110$.

S 112(2).

8 See Naudé "The Consumer's Right to Fair, Reasonable and Just Terms under the new Consumer Protection Act in Comparative Perspective" 2009 SALJ 505; Sharrock "Judicial Control of Unfair Contract Terms: The Implications of the Consumer Protection Act" 2010 SA Merc LJ 295; Jacobs, Stoop, and Van Niekerk "Fundamental Consumer Rights under the Consumer Protection Act 68 of 2008: A Critical Overview and Analysis" 2010 PELJ 3; Naudé "Enforcement Procedures in Respect of the Consumer's Right to Fair, Reasonable and Just Contract Terms under the Consumer Protection Act in Comparative Perspective" 2010 SALJ 515; Du Plessis "Protecting Consumers Against Unconscionable Conduct: Section 40 of the Consumer Protection Act 68 of 2008" 2012 THRHR 24; Barnard "The Influence of the Consumer Protection Act 68 of 2008 on the Warranty Against Latent Defects, Voetstoots Clauses and Liability for Damages" 2012 De Jure 455; Barnard "The Influence of the Consumer Protection Act 68 of 2008 on the Common Law Warranty Against Eviction: A Comparative Overview" 2012 PELJ 5; Glover "Section 40 of the Consumer Protection Act in Comparative Perspective" 2013 TSAR 689; and Stoop "The Overlap between the Consumer Protection Act 68 of 2008 and the National Credit Act 34 of 2005: A Comparison with Australian Law" 2014 THRHR 135.

9 Otto "Verborge gebreke, Voetstootsverkope, die Consumer Protection Act en die National Credit Act" 2010 THRHR 525535. 
This article focuses on three sections of the Act requiring careful consideration in the context of transactions relating to immovable property ("property transactions"). The first (section 13(1)) concerns "linked" agreements (also known as "tying arrangements"10); the second (section 14) deals with so-called fixed-term agreements, while the third (section 50(2)(a)) relates to unsigned written agreements. In respect of each of these sections the question arises whether the provision applies to property transactions and, if so, to what extent. To place the discussion in context it is necessary first to analyse the application of the Act to property transactions. It is also essential to examine briefly how the Act is to be interpreted.

\section{APPLICATION OF THE ACT TO PROPERTY TRANSACTIONS}

Understanding the application of the Act requires an analysis of section 5 read with a number of definitions in section 1, including that of "transaction", "consumer", "business", "supply", "supplier", "service", "promote", "market" and "goods". In terms of section 5(1)(a) the Act applies to all transactions "occurring" in South Africa, subject to certain exceptions. In this context the word "occurring" is vague and confusing ${ }^{11}$ but it is probably safe to say that it covers transactions entered into or concluded in the RSA. A "transaction" is defined as meaning -

"(a) in respect of a person acting in the ordinary course of business -

(i) an agreement between or among that person and one or more other persons for the supply or potential supply of any goods or services in exchange for consideration; or

(ii) the supply by that person of any goods to or at the direction of a consumer for consideration; or

(iii) the performance by, or at the direction of, that person of any services for or at the direction of a consumer for consideration; or

(b) an interaction contemplated in section 5(6), irrespective of whether it falls within paragraph (a)."

The expression "agreement" means "an arrangement or understanding between or among two or more parties that purports to establish a relationship in law between or among them". "Supply" when used as a verb means -

"(a) in relation to goods, includes sell, rent, exchange and hire in the ordinary course of business for consideration; or

(b) in relation to services, means to sell the services, or to perform or cause them to be performed or provided, or to grant access to any premises, event, activity or facility in the ordinary course of business for consideration."

"Goods" include (amongst others) "a legal interest in land or any other immovable property, other than an interest that falls within the definition of "service". "Business" means the "continual marketing of any goods or

10 See Van Eeden A Guide to the Consumer Protection Act (2009) 127.

11 See Du Preez "The Consumer Protection Bill: A Few Preliminary Comments" 2009 TSAR 5867. 
services". "Market", when used as a verb, means to "promote or supply any goods or services". "Promote" means to -

"(a) advertise, display or offer to supply any goods or services in the ordinary course of business, to all or part of the public for consideration;

(b) make any representation in the ordinary course of business that could reasonably be inferred as expressing a willingness to supply any goods or services for consideration; or

(c) engage in any other conduct in the ordinary course of business that may reasonably be construed to be an inducement or attempted inducement to a person to engage in a transaction."

The expression "service" includes, amongst others, "any work or undertaking performed by one person for the direct or indirect benefit of another". A "supplier" is a person who markets goods and services while a "consumer" in respect of any particular goods or services includes, amongst others -

"(a) a person to whom those particular goods or services are marketed in the ordinary course of the supplier's business;

(b) a person who has entered into a transaction with a supplier in the ordinary course of the supplier's business, unless the transaction is exempt from the application of this Act by section 5(2) or in terms of section 5(3);

(c) if the context so requires or permits, a user of those particular goods or a recipient or beneficiary of those particular services, irrespective of whether that user, recipient or beneficiary was a party to a transaction concerning the supply of those particular goods or services."

Section 5(2) excludes certain transactions from the operation of the Act. Relevant for present purposes are transactions whereby goods or services are promoted or supplied to the State; transactions constituting credit agreements under the National Credit Act 34 of 2005, and transactions in terms of which the consumer is a juristic person whose asset value or annual turnover, at the time of the transaction, equals or exceeds the threshold value determined by the Minister. This threshold has been fixed at R2 million. ${ }^{12}$ A "juristic person" includes a body corporate, partnership, association and a trust. ${ }^{13}$

Putting it all together, in the context of property transactions the application of the Act comes to this:

The Act applies to sale and lease agreements entered into by sellers and lessors selling and letting immovable property in the ordinary course of business, except where -

(a) the purchaser or lessee is the State;

(b) the purchaser or lessee is a juristic person having an asset value or annual turnover of R2 million or more at the time of entering into the agreement; or 
(c) in the case of an instalment sale of land, the transaction constitutes a credit agreement under the National Credit Act 34 of $2005 .{ }^{14}$

Typically the Act regulates sale and lease agreements entered into by property developers, speculators and investors selling or letting property on a continuous basis, subject to the exceptions mentioned. In the context of the Act these persons are referred to as "suppliers", while purchasers and lessees protected by the Act are called "consumers". Consumers are not confined to private individuals, but include business entities actively carrying on business.

Sale and lease agreements entered into by sellers and lessors who do not sell or let in the ordinary course of business are not subject to the Act. As stated above, "business" is defined as the continual marketing of any goods or services. A once-off sale or lease agreement concluded by a home owner is therefore not governed by the Act, irrespective of whether or not such agreement has been negotiated by an estate agent acting for one of the parties..$^{15}$ It is uncertain, however, at what stage the repeated letting of a house by a home owner can be described as the continual marketing of the property; evidently each case will have to be treated on its own having regard to the particular circumstances.

Mandate agreements entered into between estate-agency firms and their clients fall under the Act, except where the client is the State or a juristic person having an asset value or annual turnover of R2 million or more at the time of concluding the mandate. In the terminology of the Act the estate-agency firm is the "supplier" and the client the "consumer".

A regulatory authority may apply to the Minister for an industry-wide exemption from one or more provisions of this Act on the grounds that those provisions overlap or duplicate a regulatory scheme administered by that regulatory authority in terms of any other national legislation, treaty, international law, convention or protocol. ${ }^{16}$ The Estate Agency Affairs Board is therefore empowered to seek the exemption of estate agents from some or all of the provisions of the Act on the grounds that estate agents' affairs are regulated by the Estate Agency Affairs Act 112 of 1976. To date no such exemption has been granted.

The Act does not apply to mortgage-bond agreements between banks and purchasers of immovable property. Such agreements are credit agreements under the National Credit Act 34 of $2005^{17}$ and the Consumer Protection Act does not apply to any transaction constituting a credit agreement under the National Credit Act. ${ }^{1}$

\footnotetext{
The property sold on instalments is, however, not excluded from the Act: s 5(2)(d)).

See Barnard 2012 De Jure 474.

$S 5(3)(a)$ and (b).

See the definition of "mortgage agreement" in $\mathrm{s} 1$ of the National Credit Act.

$S 5(2)(d)$.
} 


\section{INTERPRETATION OF THE ACT}

A comprehensive analysis of the approach to be adopted in the interpretation of statutes falls outside the scope of this article. A brief synopsis is sufficient:

- In terms of the traditional "golden rule" of interpretation - generally referred to as the textual or literal approach - the key objective is to ascertain the intention of the legislature having regard to the words used in the Act. If the words are unambiguous effect must be given to their ordinary, grammatical meaning, unless this leads to some absurdity, inconsistency, hardship or anomaly which the legislature could not have intended having regard to the Act as a whole. ${ }^{19}$ If the words are ambiguous, vague or unclear they must be interpreted in a manner whereby effect is given to the policy and object of the statute in question. ${ }^{20}$ Such "purposive construction" is, however, not permitted where the words are clear and unambiguous since a "(j)udge has authority to interpret, but not to legislate, and he cannot do violence to the language of the lawgiver by placing upon it a meaning of which it is not reasonably capable, in order to give effect to what he may think to be the policy or object of the particular measure". ${ }^{21}$

- In contrast to the literal approach, the purposive or contextual approach to the interpretation of statutes places less emphasis on the literal meaning of the words and focuses more on the context in which the words are used. Schreiner JA explained the process as follows in a minority judgment in Jaga $v$ Dönges, $N O:^{22}$

"Certainly no less important than the oft repeated statement that the words and expressions used in a statute must be interpreted according to their ordinary meaning is the statement that they must be interpreted in the light of their context. But it may be useful to stress two points in relation to the application of this principle. The first is that 'the context', as here used, is not limited to the language of the rest of the statute regarded as throwing light of a dictionary kind on the part to be interpreted. Often of more importance is the matter of the statute, its apparent scope and purpose, and, within limits, its background. The second point is that the approach to the work of interpreting may be along either of two lines. Either one may split the inquiry into two parts and concentrate, in the first instance, on finding out whether the language to be interpreted has or appears to have one clear ordinary meaning, confining a consideration of the context only to cases where the language appears to admit of more than one meaning; or one may from the beginning consider the context and the language to be interpreted together."

19 Bhyat $v$ Commissioner for Immigration 1932 AD 125 129; S v Tieties 1990 (2) SA 461 (A); and Poswa $v$ Member of the Executive Council for Economic Affairs, Environment and Tourism, Eastern Cape 2001 (3) SA 582 (SCA).

20 Dadoo Ltd v Krugersdorp Municipal Council 1920 AD 530 543; and Public Carriers Association v Toll Road Concessionaries (Pty) Ltd 1990 (1) SA 925 (A) 942.

21 Dadoo Ltd v Krugersdorp Municipal Council supra.

221950 (4) SA $653(A)$. 
Adopting this line of reasoning Wessels AJA expressed the proper approach to statutory interpretation as follows in Stellenbosch Farmers' Winery Ltd v Distillers Corporation (SA) Ltd: ${ }^{23}$

\begin{abstract}
"In my opinion it is the duty of the Court to read the section of the Act which requires interpretation sensibly, ie with due regard, on the one hand, to the meaning or meanings which permitted grammatical usage assigns to the words used in the section in question and, on the other hand, to the contextual scene, which involves consideration of the language of the rest of the statute, as well as the 'matter of the statute, its apparent scope and purpose, and within limits, its background'. In the ultimate result the Court strikes a proper balance between these various considerations and thereby ascertains the will of the Legislature and states its legal effect with reference to the facts of the particular case which is before it."
\end{abstract}

Despite this recognition of the purposive method of interpretation of statutes $^{24}$ it was not always clear in earlier years whether such method could be adopted only in cases where the words used were ambiguous, or whether it could be applied even if the plain meaning of the words were clear and without any ambiguity. In University of Cape Town v Cape Bar Councili ${ }^{5}$ Rabie CJ expressed the opinion that the words of an Act "clear and unambiguous as they may appear to be on the face thereof, should be read in the light of the subject-matter with which they are concerned, and that it is only when that is done that one can arrive at the true intention of the Legislature". However, in Public Carriers Association $v$ Toll Road Concessionaries (Pty) Ltd ${ }^{26}$ Smalberger JA appears to have favoured a purposive interpretation only in cases of ambiguity:

"Mindful of the fact that the primary aim of statutory interpretation is to arrive at the intention of the Legislature, the purpose of a statutory provision can provide a reliable pointer to such intention where there is ambiguity."

The University of Cape Town decision found support in Thoroughbred Breeders' Association v Price Waterhouse, ${ }^{27}$ where the Supreme Court of Appeal, quoting the opinion expressed by Rabie CJ, stated unequivocally that " $(\mathrm{t})$ he days are long past when blinkered peering at an isolated provision in a statute was thought to be the only legitimate technique in interpreting it if it seemed on the face of it to have a readily discernible meaning". This in turn prompted the Constitutional Court to observe that "(t)he emerging trend in statutory construction is to have regard to the context in which the words occur, even where the words to be construed are clear and unambiguous". ${ }^{28}$

- Section 39(2) of the Constitution obliges a court to promote the spirit, purport and objects of the Bill of Rights when interpreting any legislation.

1962 (1) SA 458 (A) $476 \mathrm{E}-\mathrm{G}$

24 See too Desert Palace Hotel Resort (Pty) Ltd v Northern Cape Gambling Board 2007 (3) SA 187 (SCA).

251986 (4) SA $903($ A).

$26 \quad 1990$ (1) SA 925 (A) 942.

2001 (4) SA 551 (SCA)

28 Bato Star Fishing (Pty) Ltd v Minister of Environmental Affairs 2004 (4) SA 490 (CC). 
The provision effectively entrenches "the technique of paying attention to context in statutory construction". ${ }^{29}$

Based on the foregoing it appears to be safe to state that the literal approach to the interpretation of statutes is no longer the golden rule it used to be, and that nowadays a purposive interpretation is to be applied even if the words used in a statute are clear and unambiguous having regard to their plain meaning. Exactly what this means was explained as follows by Lord Denning in James Buchanan \& Co Ltd v Babco Forwarding \& Shipping Co Ltd: $:^{30}$

"All it means is that the Judges do not go by the literal meaning of the words, or by the grammatical structure of the sentence. They go by the design or purpose which lies behind it. When they come on a situation which is to their minds within the spirit - but not the letter - of the legislation, they solve the problem by looking at the design and purpose of the legislation - at the effect which it was sought to achieve. They then interpret the legislation so as to produce the desired effect. This means that they fill the gaps, quite unashamedly, without hesitation. They ask simply: What is the sensible way of dealing with this situation so as to give effect to the presumed purpose of the legislation? They lay down the law accordingly.'

The exposition above describes the method to be applied generally to the interpretation of all statutes, including the Consumer Protection Act. A number of sections of the latter Act specifically deal with interpretation issues, but they do not override the general approach to be followed. In fact, they simply underscore the purposive method of interpretation by setting out certain specific factors or matters to be taken into account in the process of the interpreting the Act. For present purposes section 2, entitled "Interpretation", and section 4(3) are of relevance. Sections 2(2)(a) and (b) stipulate that, when interpreting or applying the Act consideration may be given to appropriate foreign and international law, as well as appropriate international conventions, declarations or protocols relating to consumer protection. Subsection (1) directs that the Act has to be interpreted "in a manner that gives effect to the purposes set out in section 3". Given the importance of the section in the context of this article it is essential to quote section 3(1) in full:

"3(1) The purposes of this Act are to promote and advance the social and economic welfare of consumers in South Africa by -

(a) establishing a legal framework for the achievement and maintenance of a consumer market that is fair, accessible, efficient, sustainable and responsible for the benefit of consumers generally;

(b) reducing and ameliorating any disadvantages experienced in accessing any supply of goods or services by consumers -

(i) who are low-income persons or persons comprising low-income communities;

(ii) who live in remote, isolated or low-density population areas or communities;

(iii) who are minors, seniors or other similarly vulnerable consumers; or

\footnotetext{
Ngcobo J in Bato Star Fishing (Pty) Ltd v Minister of Environmental Affairs supra par [91]. [1977] 1 All ER 518 522-523.
} 
(iv) whose ability to read and comprehend any advertisement, agreement, mark, instruction, label, warning, notice or other visual representation is limited by reason of low literacy, vision impairment or limited fluency in the language in which the representation is produced, published or presented;

(c) promoting fair business practices;

(d) protecting consumers from -

(i) unconscionable, unfair, unreasonable, unjust or otherwise improper trade practices; and

(ii) deceptive, misleading, unfair or fraudulent conduct;

(e) improving consumer awareness and information and encouraging responsible and informed consumer choice and behaviour;

(f) promoting consumer confidence, empowerment, and the development of a culture of consumer responsibility, through individual and group education, vigilance, advocacy and activism;

(g) providing for a consistent, accessible and efficient system of consensual resolution of disputes arising from consumer transactions; and

(h) providing for an accessible, consistent, harmonised, effective and efficient system of redress for consumers."

Section 4(3) expressly provides for a purposive interpretation of the Act. It stipulates that, if any provision of the Act, read in context, can reasonably be construed to have more than one meaning "the Tribunal or court must prefer the meaning that best promotes the spirit and purposes of this Act, and will best improve the realisation and enjoyment of consumer rights generally, and in particular by persons contemplated in section 3(1)(b)". This does not mean that a purposive interpretation is to be adopted only in cases of ambiguity: what it means is that, if a purposive interpretation reveals that a provision can be read in more than one way, the choice between those meanings must be made by applying the provisions of section 4(3).

The inescapable conclusion is that there can be no doubt that the Consumer Protection Act has to be interpreted purposively. Accordingly, when interpreting the Act the focus falls not on the literal meaning of the words but on the broad policy, purpose and spirit of the Act, the aim being to give effect thereto. This calls for a clear understanding of what the Act seeks to achieve. In general terms the policy, purpose and spirit of the Act is to lay down certain standards and norms to promote the fair and responsible treatment of consumers in their business dealings in the marketplace. It is not the aim of the Act to destroy, hamper or distort sound business practices or to side with consumers at all cost. The promotion of fairness does not require that consumers be protected to the extreme, or that consumers be given the right in all instances to escape from the consequences of their business transactions simply because they changed their minds. The Act seeks to protect consumers against exploitation, unfair treatment and unscrupulous business practices, not to empower consumers to act deceitfully or to exploit suppliers. Consumer protection is not about rights only; it concerns obligations too, and nothing in the Act suggests that it has to be interpreted in manner whereby consumers need not take responsibility for their decisions in circumstances where no unfairness or unreasonable conduct is attributable to suppliers. A balance must be struck between the legitimate expectations of consumers on the one hand, and that of suppliers on the other. What is required is a sensible interpretation of the Act, not an 
interpretation skewed towards consumers without properly evaluating the notion of fairness.

\section{SECTION 13(1): LINKED AGREEMENTS}

Section 13(1) stipulates that no supplier may offer any goods or services to a consumer (or enter into an agreement or transaction with a consumer) on the basis that the consumer is obliged to -

(a) purchase any other particular goods or services from that supplier;

(b) enter into an additional agreement or transaction with the same supplier or a designated third party; or

(c) agree to purchase any particular goods or services from a designated third party,

unless the supplier offers bundled goods or services separately and at individual prices, or if he can show that (i) the convenience of bundling the goods or services outweighs the limitations imposed on the consumer; or (ii) the bundling of the goods or services results in economic benefit for consumers.

The practice of bundling is found in many business transactions. A typical example is where computer equipment is sold on the basis that the operational software and print cartridges must be purchased from the same supplier otherwise the warranty on the goods lapses. In the property industry it is encountered in situations where developers sell vacant land in development schemes on a plot-and-plan basis, whereby the land transaction is linked to an obligation imposed on the purchaser to enter into a building contract with a particular builder to construct the dwelling on the land. Lease agreements too are at times structured as linked transactions, such as where the lease imposes an obligation on the lessee to engage the services of a particular security company or garden service.

Sale and lease agreements structured in this way are governed by section $13(1)$ in that they impose a duty on the consumer to enter into an additional agreement or transaction with the same supplier or a designated third party. The conclusion of an agreement on this basis is prohibited unless it can be brought within one of the exceptions stated in section 13(1). Property developers may have some difficulty in establishing that the convenience of bundling the sale of the plot and the building contract outweighs the limitations imposed on the consumer, or that such bundling results in economic benefit for consumers. This would be particularly so in cases where the consumer wishes to use his own builder at a competitive price. To comply with section 13(1) the developer thus has no choice but to offer the bundled goods and services separately and at individual prices. In this respect it is not clear whether the offer to construct a dwelling must be made to the public at large or whether it would be sufficient to give a purchaser of a plot the choice of entering into one of several individually priced building contracts. In other words, must the developer offer the plots to the general public and then separately from that also offer his services as a builder to the general public at a separate price? The mischief that the provision apparently seeks to address is the situation where a consumer purchases a 
plot tied to an obligation to build a house, but the cost of the house is not specified and the consumer eventually discovers that he has bought the plot but cannot afford the building costs. In the circumstances it is submitted that section 13(1) is to be interpreted on the basis that property developers may sell vacant land on a plot-and-plan basis as long as they allow the consumer to select a building plan from one or more sketch plans and the construction costs of each of the dwellings are priced separately from the land cost.

Lessors may possibly face more difficulties, depending on the circumstances. The reason why lessors of townhouses in complexes sometimes oblige their lessees to engage the services of a particular security company is because the complex has a specific arrangement with the security company in question to gain access. In these circumstances it would probably not be difficult for the lessor to show that the convenience of bundling the lease and the security-company contract outweighs the limitations placed on the consumer, provided it can be established that the services of the security company are beneficial to the lessee, directly or indirectly. Alternatively, the lessor may simply include the cost of the security service in the rental and offer the lease of the premises on the basis that a security service is included. That takes the matter outside the ambit of section 13(1).This would probably also be the most practical way to deal with the garden service. The reason why the lessor would require the gardening service is because (a) he wants to ensure that the garden is properly maintained, and (b) he is familiar with the standard of service rendered by the gardening company in question. However, it may be difficult to bring the bundling of the two agreements within one of the exceptions listed in section $13(1)$, especially if the lessee is willing and able to maintain the garden himself at a cost lower than what the garden-service charges. A lessor faced with this situation will therefore be well advised to rather include the cost of the garden service in the rental and offer the garden maintenance as part of the lease.

\section{SECTION 14: FIXED-TERM AGREEMENTS}

Sections $14(1)-(3)$ read as follows:

"(1) This section does not apply to transactions between juristic persons regardless of their annual turnover or asset value.

(2) If a consumer agreement is for a fixed term -

(a) that term must not exceed the maximum period, if any, prescribed in terms of subsection (4) with respect to that category of consumer agreement;

(b) despite any provision of the consumer agreement to the contrary -

(i) the consumer may cancel that agreement -

(aa) upon the expiry of its fixed term, without penalty or charge, but subject to subsection (3)(a); or

(bb) at any other time, by giving the supplier 20 business days' notice in writing or other recorded manner and form, subject to subsection (3)(a) and (b); or

(ii) the supplier may cancel the agreement 20 business days after giving written notice to the consumer of a material failure by the consumer to comply with the agreement, unless the consumer has rectified the failure within that time; 
(c) of not more than 80 , nor less than 40 , business days before the expiry date of the fixed term of the consumer agreement, the supplier must notify the consumer in writing or any other recordable form, of the impending expiry date, including a notice of -

(i) any material changes that would apply if the agreement is to be renewed or may otherwise continue beyond the expiry date; and

(ii) the options available to the consumer in terms of paragraph (d); and

(d) on the expiry of the fixed term of the consumer agreement, it will be automatically continued on a month-to-month basis, subject to any material changes of which the supplier has given notice, as contemplated in paragraph (c), unless the consumer expressly -

(i) directs the supplier to terminate the agreement on the expiry date; or

(ii) agrees to a renewal of the agreement for a further fixed term.

(3) Upon cancellation of a consumer agreement as contemplated in subsection (1)(b) -

(a) the consumer remains liable to the supplier for any amounts owed to the supplier in terms of that agreement up to the date of cancellation; and

(b) the supplier -

(i) may impose a reasonable cancellation penalty with respect to any goods supplied, services provided, or discounts granted, to the consumer in contemplation of the agreement enduring for its intended fixed term, if any; and

(ii) must credit the consumer with any amount that remains the property of the consumer as of the date of cancellation, as prescribed in terms of subsection (4)."

Two related questions are addressed in this article: firstly, whether section 14 applies to sole mandates conferred on estate agents; secondly, whether the section governs leases of immovable property. In terms of the estate agents' code of conduct $^{31}$ a sole mandate must contain an expiry date expressed as a calendar date, the result being that in practice ${ }^{32}$ estateagency sole mandates are all conferred for a fixed period agreed to by the parties. Lease agreements may be entered into on a periodical basis, or the period of the lease may be fixed by the parties, for example two or three years. Are these agreements fixed-term agreements as contemplated by section 14 ?

Most legal advisors, ${ }^{33}$ property practitioners ${ }^{34}$ and auditors ${ }^{35}$ appear to have no difficulty in accepting that section 14 applies to fixed-period

31 Clause 3.3.2.

32 The code of conduct is not law and cannot be enforced in a court. However, an estate agent in breach of the code of conduct may face disciplinary action in terms of the Estate Agency Affairs Act 112 of 1976 . Certain penalties may be imposed if the estate agent is found guilty of a contravention of the code of conduct, including the withdrawal of the estate agent's fidelity-fund certificate. Such withdrawal will compel the estate agent to leave the estate agency business. For that reason estate agents prefer to abide by the code of conduct.

33 See the following websites (accessed 2014-03-03 to 2014-03-16): http://www.fluxmans.com /news/display.asp?id=112 (Fluxmans); http://jacobson.co.za/2012331does-the-consumerprotection-act-apply-to-residential-leases-html/ (Jacobson Attorneys); http://www.werks mans.com/virt_media/1729/ (Werksmans); http://www.matterresolved.co.za/publications /consumer-protection-act-impact-on-lease-agreements/ (Rubinstein Attorneys); http://www. stbb.co.za/mapics/LEASES\%20CPA.pdf (STBB Attorneys); http://natalielubbe.co.za/online/ node/12 (Natalie Lubbe and Associates); http://miltons.law.za/assets/uploaded_news 
leases. ${ }^{36}$ Only a handful disagree. ${ }^{37}$ Some are hesitant to state categorically that section 14 applies to sole mandates ${ }^{38}$, while others simply accept that it does. ${ }^{39}$ Confusion reigns.

On a literalist approach, giving the expression its plain, ordinary meaning, a fixed-term agreement is any agreement where the duration of the agreement is set between two dates, namely a commencement date and an expiry date. The period between the two dates could be any number of days, weeks, months or years as long as it is fixed. In that sense a seven-day carrental agreement is a fixed-term agreement, as is a two-year mobile telephone contract and a one-year health-club contract. The same applies to fixed-period lease agreements and sole mandates, whatever their duration. Thus a 20-year registered long lease of business premises is a fixed-term agreement, as well as a 14-day rental of accommodation in a holiday-resort and a 30-day sole mandate. However, section 14 appears not to apply to all fixed-term agreements irrespective of the duration thereof. In terms of subsection (2)(c) the supplier party to a fixed-term agreement must at least 40 business days before the expiry of the agreement notify the consumer of the impending expiry date. Logically it would be impossible to comply with this directive unless the period of the agreement is 40 business days or

flashes/NEWSFLASH_Fixed_Term_Lease_Agreements_2.pdf (Miltons); http://www.esse laar.co.za/legal-articles/lease-and-consumer-protection-act-68-2008-lets-set-record-straight (Esselaar Attorneys); http://www.hg.org/article.asp?id=26544 (Alan Levy Associates); http:// www.bowman.co.za/News-Blog/Blog/Consumer-Protection-Act-Make-Property-Harder-to-

Rent-For-Tenants (Bowman Gilfillan); http:/www.schoemanlaw.co.za/wp-content/uploads/ 2010/11/Residential-lease-agreements-and-the-CPA.pdf; (Schoeman Attorneys); http://www .polity.org.za/article/the-consumer-protection-act-and-lease-agreements-2011-11-30

(Bouwer Kobeli Morabe).

34 See the following websites (accessed 2014-03-03 to 2014-03-16): https://www.iol property.co.za/roller/news/entry/protecting_the_landlord_and_tenant; www.rivigangroup. com/2011/11/cpa-and-long-term-leases.html; www.lettingworx.co.za/blog/item/the-consu mer-protection-act-and-lease-agreements.html; http://www.spire.co.za/29.html; http://www. propertyprobe.co.za/Consumer_Protection_Act.html; http://www.rawson.co.za/news/newcpa-rules-entitle-a-tenant-to-cancel-a-lease-but-this-can-be-costly-id-917; http://www.max prop.co.za/news/cpa-lease-agreements-when-may-they-exceed-24-months/.

35 See the following websites (accessed 2014-03-03 to 2014-03-16): http://www.tuffias sandbergksi.co.za/news/2011/TuffiasNews Jun2011.pdf (Tuf fias Sandberg KSI); http:// newsletter.profmark.co.za/za members/14145/ttp/June\%202011/CPA\%20and\%20Resident ial\%20Leases.pdf (Nolands); https://www.kpmg.com/ZA/en/lssuesAndlnsights/Articles Publications/Tax-and-Legal-Publications/Documents/Consumer\%20Prot\%20Act\%20Booklet \%20Sept\%202010.pdf (KPMG).

36 Neither does the Estate Agency Affairs Board: www.eaab.org.za_uploads files how_consumer_protection_act_effects_lease_of_property_.pdf (accessed 2014-03-05).

37 http://businessday.newspaperdirect.com/epaper/viewer.aspx (Deneys Reitz) (accessed 2014-03-08); http://www.michalsons.co.za/the-consumer-protection-act-does-not-apply-toall-lease-agreements/9814 (Michalsons) (accessed 2014-03-08); http://www.commercialproperty.co.za/3766_news_SAPOA-seeks-clarity-on-Consumer-Protection-Act-.html (SAPOA) (accessed 2014-03-08).

38 http://www.miltons.law.za/assets/uploaded_newsflashes/newsflash_sole_mandate_and_ fixed_term_agreements.pdf; http://www.amchunter.co.za/news_detail.php?title= How ${ }^{-}$will The Consumer Protection Act Impact on You and the Estate Agent (both websites accessed 2014-03-05).

39 http://www.fluxmans.com/news/display.asp?id=112; http://www.greyvensteins.co.za/estateagents-commision/; http://harcourtsplatinum.wordpress.com/tag/sole-mandate/; http://inter netmarketingconsultantsa.co.za/cpa-estate-agents-mandates; www.newcastleclassifieds.co $. z a / ? p=120$ (both accessed 2014-03-04). 
more. Accordingly, based on its own wording section 14 appears not to apply to "short" fixed-term agreements, only to agreements having a minimum fixed period of 40 business days. Expressed in terms of months, it means a fixed term of at least two months.

Useful as it may be to determine the plain, ordinary meaning of a fixedterm agreement, such meaning is not necessarily the correct interpretation of the expression in the context of section 14. As explained earlier, the Act needs to be interpreted purposively, not from a literalist angle. The question is not what a fixed-term agreement literally means, but what it means having regard to the context of the Act and its objectives. As stated above, in general terms the purpose of the Act is to promote the fair and responsible treatment of consumers in their business dealings in the marketplace. Accordingly, what must be asked is: what meaning is to be attributed to the expression "fixed-term agreement" to give effect to that purpose? Based on this approach, dealing with the matter sensibly as Lord Denning said, it is submitted that neither sole mandates nor fixed period lease agreements are fixed-term agreements as contemplated in section 14; therefore neither of them is governed by any of the provisions of the section.

A purposive interpretation of section 14 must take into account the following:

Section 14 does not apply to transactions where both parties are juristic persons, regardless of their annual turnover or asset value. ${ }^{40}$ This is of particular significance in relation to leases of commercial and industrial premises, where landlords are invariably juristic persons. If section 14 is to apply to lease agreements these landlords can simply escape from its application by giving preference to tenants who too are juristic persons. In fact, this is already occurring in practice given the weight of opinion that section 14 does apply to fixed-term lease agreements. ${ }^{41}$ In doing so landlords eliminate the commercially unacceptable provisions of subsection (2)(b)(i)(bb) in terms of which the tenant may cancel the lease before its expiry on 20 business days' notice. They are also not bound to subsection (2)(b)(ii) whereby the lease may be cancelled by the landlord only after 20 business days' notice to the tenant of a material breach, and only if the tenant has failed to rectify the breach within that time. The outcome of this is that tenants who are not legal entities may face difficulties in securing leases in commercial premises, and they will in effect be compelled to form companies or trading trusts to do so. How does this promote the purposes of the Act?

In terms of the regulations promulgated under the $\mathrm{Act}^{42}$ the maximum period of a fixed-term agreement is 24 months from the date of signature by the consumer unless a longer period is expressly agreed with the consumer and the supplier can show a "demonstrable financial benefit" to the consumer. A typical example of a financial benefit is a price discount

$40 \mathrm{~S}$ 14(1).

41 http://www.bowman.co.za/News-Blog/Blog/Consumer-Protection-Act-Make-Property-Harder -to-Rent-For-Tenants (accessed 2014-03-05); http://www.pmbproperty.co.za/news/expertattorney-clarifies-cpa/ (accessed 2014-03-14).

42 R 5(1) of GN 294 in GG 34181 of 2011-04-01. 
granted in respect of fixed-term agreements extending over a period longer than 24 months. However, such discounts are not common practice in the letting market, and in practice it may not always be a straightforward exercise for a lessor to discharge the onus of showing that a fixed-term lease longer than 24 months benefits the lessee financially. If section 14 is to apply to lease agreements and a lessor cannot discharge the onus, the maximum period of a lease agreement will therefore be 24 months, irrespective of whether the lessee desperately wishes to enter into a lease for a longer period. How does this benefit the consumer? In the commercial letting market the emphasis is more often than not on the minimum period of the fixed-term lease, not the maximum. For that reason some jurisdictions have introduced laws specifying a minimum lease period of five years in relation to leases of retail premises, subject to certain exceptions. ${ }^{43}$ A two-year limitation may seriously prejudice lessees of commercial and industrial premises because banks may be slow to grant credit to consumers to start up a business if their lease agreements are limited to two years, the period being too short to enable consumers to recover the start-up costs.

If section 14 is to apply to lease agreements, subsection (2)(b)(ii) will prohibit a lessor from cancelling a lease in the event of a material breach of contract by the lessee unless (i) the lessor has given the lessee 20 business days' notice of the breach and (ii) the lessee has failed to remedy the breach within that period. In practical terms this would mean that should a lessee fail to pay the rent the lessor may not cancel the lease if the lessee settles the arrears within the 20 business days' notice period. It matters not how many times such failure occurred in the past: in respect of each non-payment the 20 business days' notice must be given and the lessor is prohibited from cancelling the lease if the lessee pays up during that period. Effectively this will allow a lessee to default each month, assured that the lease cannot be cancelled as long as the rent is paid within the 20 business days' notice period. Health clubs and mobile telephone-service providers do not face similar problems since they are not pressed to cancel the agreement should the consumer default; they simply discontinue their services until the arrears are paid. However, lessors have no such leverage and the only effective remedy at their disposal is to cancel the lease should the lessee continuously commit breach of contract. Lease agreements usually include a clause whereby the lessor may cancel the lease in the event of repeated non-payment of rent or other breaches of the lease by the lessee, but this will now be prohibited if section 14 is to apply to fixed-term lease agreements. It is hard to see how this promotes the purposes of the Act. As stated above, the Act seeks to protect consumers against exploitation, unfair treatment and unscrupulous business practices, not to empower consumers to act deceitfully or to exploit suppliers. It is not unfair for a lessor to cancel a lease in cases of on-going and repeated breaches by the lessee, and

43 See s 16 of the Retail Leases Act 46 of 1994 (New South Wales) and s 21 of the Retail Leases Act 4 of 2003 (Victoria).

44 Comment by the CEO of SAPOA: http://www.commercial-property.co.za/3766 news SAPOA-seeks-clarity-on-Consumer-Protection-Act-.html (accessed 2014-03-14). 
prohibiting a lessor from doing so would effectively allow lessees to act unscrupulously. Surely, this does not serve the aims of the Act.

In terms of subsection (2)(d) a fixed-term agreement does not terminate at expiry of the fixed term, unless the consumer expressly directs the supplier to do so. If no such directive is given the agreement automatically continues on a month-to-month basis. This type of arrangement is understandable in cases of health club contracts and mobile telephone agreements since the suppliers would generally have no objection to the agreement continuing after its expiry. However, in the case of lease agreements not all lessors would necessarily wish to continue with the lease beyond its expiry date. If section 14 is to apply to leases it would mean that to terminate the lease the lessor would have to give a month's notice at the expiry date, and the lease will terminate only at the end of the notice period. In other words, a lessor will never be able to obtain occupation of the premises on termination of the fixed period despite the fact that no provision is made in the lease for its continuation after the lapse of the fixed period - the earliest that the lessor will be able to do so is one month after the expiry of the lease. This is rather absurd, even more so when applied to sole mandates. If section 14 is to govern sole mandates the effect would be that a sole mandate continues on a month-to-month basis after the initial expiry date, unless the consumer directs the estate agent to terminate it. Should the consumer inadvertently fail to do so and confer a mandate on another estate agent after the initial expiry date of the sole mandate, this would constitute breach of the sole agency and expose the consumer to a damages claim. It must be remembered also that a sole mandate effectively gives the estate agent a monopoly on marketing the property during the sole mandate period, and if section 14 is to apply to such mandates the outcome will be that the estate agent's monopoly will continue indefinitely unless it is terminated by the consumer. If anything this runs counter to the purposes of the Act. What benefit is there for the consumer to continue with the sole mandate on a month-to-month basis after the expiry of the initial fixed period, and why burden the consumer with the obligation to terminate it on the expiry thereof?

In terms of subsection (2)(b)(i)(bb) a consumer may at any time cancel a fixed-term agreement prior to the expiry thereof, subject to payment of a reasonable cancellation penalty imposed by the supplier under subsection (3)(b)(i). Regulation 5(2) lists the factors to be taken into account in determining the penalty, some of which play no role in determining a supplier's losses in the event of an early termination of lease agreements and sole mandates. Fixed-term lease agreements invariably contain clauses to the effect that should the lessee abandon the lease prematurely he assumes liability for the full amount of the rental up to the expiry date or until a replacement lessee is found, whichever occurs first. Sole mandates usually stipulate that early termination exposes the consumer to damages equalling the commission that the estate agent would have earned had the mandate been performed. However, if section 14 is to apply to these agreements clauses of this nature will be prohibited since regulation $5(3)$ stipulates that a supplier may not impose a charge "which would have the effect of negating the 
consumer's right to cancel a fixed-term consumer agreement". The regulation is obviously aimed at avoiding a situation where it would serve no purpose for a consumer to cancel a fixed-term agreement because the penalty is too onerous, such as where the consumer remains liable for all amounts owing up to the stipulated expiry date. In other words, the objective is that a consumer must be able to exercise the right to cancel the fixed-term agreement without necessarily assuming liability for the full amount of the supplier's loss. The full amount of the loss cannot be imposed as a penalty if doing so would effectively deny the consumer the right to cancel the agreement. To what extent will this establish a consumer market in the letting industry that is fair, accessible, efficient, sustainable and responsible for the benefit of consumers generally? One can understand the need for provisions of this nature in cases of healthclub contracts and mobile-telephone agreements where consumers often commit themselves hastily, without having any choice but to accept the fixed term offered by the supplier. However, tenants have a choice to negotiate the terms of their leases, in particular the duration thereof. They are not presented with fixed-term leases on a take-it or-leave-it basis; they are usually given the choice between a fixed-term and a monthly lease, and when selecting the former they are free to negotiate the period of the fixed term. Why should lessees not take responsibility for their decisions in circumstances where no unfairness or unreasonable conduct is attributable to lessors? The same applies to sole mandates: the duration of the mandate is negotiated between the parties and the consumer has total freedom to decide on the period he prefers. Why should the estate agent be deprived of the right to claim the full extent of his loss if the consumer terminates the mandate prior to the agreed expiry date? There is no unscrupulous conduct on the part of the estate agent, and no unfairness in holding the consumer to the terms of the mandate.

As stated above, foreign law may be considered when interpreting the Act. In the Australian Capital Territory (ACT) the Residential Tenancies $\mathrm{Act}^{45}$ (which applies to leases of homes only) ${ }^{46}$ stipulates that, if a tenant terminates a fixed-term lease early, the landlord may apply to the apply to the ACT Civil and Administrative Tribunal (ACAT) for compensation for the loss of the rent that the lessor would have received had the agreement continued to the end of its term, together with the reasonable costs of advertising the premises for re-letting and of giving a right to occupy the premises to another person. ${ }^{47}$ However, the compensation for loss of rent is limited to the lessor of 25 weeks rent or the rent remaining until the expiry of the lease, and advertising costs are limited to one week's rent. $^{48}$ In New South Wales the Residential Tenancies Act ${ }^{49}$

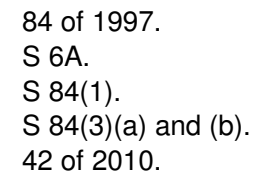


allows a tenant to terminate a fixed-term lease early without any penalty if the rent increases ${ }^{50}$ or if -

(a) the tenant has been offered, and accepted, accommodation in social housing premises;

(b) the tenant has accepted a place in an aged-care facility or requires care in such a facility;

(c) the landlord has notified the tenant of the landlord's intention to sell the residential premises and did not disclose the proposed sale before entering into the residential tenancy agreement; or

(d) a co-tenant or occupant or former co-tenant or occupant is prohibited by a final apprehended violence order from having access to the residential premises. ${ }^{51}$

In addition, the Civil and Administrative Tribunal may terminate a fixedterm agreement if it is satisfied that the tenant would in the special circumstances of the case suffer undue hardship if the residentialtenancy agreement was not terminated. ${ }^{52}$ In such instances the Tribunal has a discretion to order the tenant to pay compensation to cover the loss of the tenancy. ${ }^{53} \mathrm{~A}$ break fee may be included in a fixed-term agreement covering the amount to be paid by the tenant if the lease is abandoned, but in the absence of such clause the Tribunal may order the tenant to compensate the landlord for any loss (including loss of rent) caused by the abandonment of the premises, subject to the landlord's duty to mitigate his loss. ${ }^{54}$ Facts sheets issued by the NSW government ${ }^{55}$ state clearly that in the latter instances the tenant may have to pay the rent until a new tenant takes over or the fixed-term period ends, whichever occurs first, together with a percentage of the advertising costs and the agent's re-letting fee if the landlord uses an agent. In other words, the full extent of the landlord's loss may be claimed.

In Canada the Manitoba Residential Tenancies Act ${ }^{56}$ stipulates $^{57}$ that if the tenant abandons the premises the tenancy terminates but the the tenant remains liable, subject to the landlord's duty to minimise losses, to compensate the landlord for loss of future rent and all future tenant services charges that would have been payable under the lease agreement. In British Columbia the Residential Tenancy Act does not contain a similar provision, but fact sheets issued by the Canada Mortgage and Housing Corporation state unequivocally that tenants who give written notice to end a fixed-term tenancy agreement prior to the expiry date may be held accountable for all costs the landlord incurs in

\footnotetext{
S 99. This applies only to fixed-term leases for a period of two years or more. 
re-renting including lost rent. ${ }^{58}$ In Alberta the Residential Tenancies Act ${ }^{59}$ stipulates that, if the tenant abandons or repudiates the lease, the landlord may refuse the repudiation and hold the tenant to the lease; alternatively the landlord may accept the repudiation and recover from the tenant damages for the loss of the benefit of the fixed-term tenancy agreement until it would have expired had the landlord not accepted the repudiation, subject to the duty to mitigate the loss. UK law has essentially the same effect if no break clause is included in the lease. ${ }^{60}$ Under New Zealand law ${ }^{61}$ a tenant who abandons a fixed-term lease is liable to pay the rent for any period up to the date of the expiry of the term or the date of commencement of a new tenancy of the premises, whichever is the earlier.

Subject to one exception, in all of the jurisdictions mentioned above a lessor is entitled to claim the full extent of his loss in the event of the early termination of a fixed-term lease by the lessee, subject to the duty to mitigate the loss. This applies to all leases, including leases of residential, industrial and commercial properties. The exception is the Australian Capital Territory where the claims of lessors of homes are capped. No legislation could be found anywhere depriving an estate agent of the right to recover the full extent of his loss should the consumer terminate a sole mandate prior to its expiry date. Is there any reason why South African law should be any different?

It is submitted that section 14 is not directed to fixed-term agreements where the period of the agreement is open for negotiation between the parties and the consumer enjoys the freedom to determine the duration to suit his needs. The section is aimed at fixed-term agreements offered to consumers on a take-it-or-leave-it basis, where the supplier unilaterally determines the period and consumers have no choice but to accept the fixed term offered to them. This is typically the case in health-club contracts and mobile-telephone agreements. It is fair in these situations to allow the consumer to cancel the agreement early, subject to the payment of a reasonable penalty, since the consumer is from the outset locked into the fixed term dictated by the supplier, without having any bargaining power. That explains why fixed-term agreements are limited to two years and why the onus is on the supplier to show a "demonstrable financial benefit" to the consumer if the term is to exceed two years. However, bringing lease agreements and sole mandates under section 14 would not in any way promote the purposes of the Act but would in certain instances actually prejudice the consumer.

This does not mean that lessees and estate agents' clients are not protected by the Act. Unconscionable conduct on the part of estate agents and lessors may be challenged under section 40 , while unfair contract terms are open to scrutiny in terms of section 48 . In this respect it is worthwhile

58 http://www.cmhc-schl.gc.ca/en/co/reho/yogureho/fash/fash_002.cfm (accessed 2014-0316).

59 Statutes of Alberta, 2004 chapter R-17.1.

60 https://www.gov.uk/private-renting-tenancy-agreements/how-to-end-your-tenancy (accessed 2014-03-16). For the position in Ireland see the Residential Tenancies Act 2004.

61 S 61 of the Residential Tenancies Act 120 of 1986. 
noting that in the UK the Office of Fair Trading (OFT) has issued a guidance note explaining why it considers some clauses in lease agreements to be potentially unfair under the Unfair Terms in Consumer Contracts Regulations $1999{ }^{62}$ One such term is a clause in a fixed-term lease obliging the lessee to pay the full amount of the remaining rent in the case of an early termination by the lessee. The OFT gave the following explanation: ${ }^{63}$

"Although a landlord is normally entitled to the rent for the whole of the term,
whether or not the tenant remains in occupation, a tenant may have a valid
defence to a claim for rent. In those circumstances such a term would be an
excessive penalty. This would also allow landlords to escape their obligation
to reduce (or 'mitigate') their loss, by re-letting the property to another tenant."

6 SECTION 50(2)(a): UNSIGNED WRITTEN AGREEMENTS

Section 50(2) reads as follows:

"(2) If a consumer agreement between a supplier and a consumer is in writing, whether as required by this Act or voluntarily -

(a) it applies irrespective of whether or not the consumer signs the agreement; and

(b) the supplier must provide the consumer with a free copy, or free electronic access to a copy, of the terms and conditions of that agreement, which must -

(i) satisfy the requirements of section 22; and

(ii) set out an itemised break-down of the consumer's financial obligations under such agreement."

For present purposes the focus is on subparagraph (a). The word "applies" in the context of the provision is not entirely clear, but the section manifestly conveys that, when a consumer agreement is in writing either by reason of the provisions of the Act or voluntarily, the agreement is binding and enforceable whether or not the consumer signed the agreement. Apparently this is so even if the supplier also did not sign. A "consumer agreement" is defined in section 1 "an agreement between a supplier and a consumer other than a franchise agreement". As stated earlier, "agreement" means "an arrangement or understanding between or among two or more parties that purports to establish a relationship in law between or among them". A consumer agreement would therefore include an agreement of sale of land, as well as sale agreements of time-sharing interests, share blocks and housing interests in retirement villages. This begs the question: what is the impact of section 50(2)(a) on such agreements given the provisions of the Alienation of Land Act 68 of 1981, the Share Blocks Control Act 59 of 1980, the Property Time-sharing Control Act 75 of 1983 and the Housing Development Schemes for Retired Persons Act 65 of 1988 whereby these sale agreements are void unless they are in writing and signed by both parties or their agents acting on their written authority?

62 Guidance on unfair terms in tenancy agreements September 2005.

63 Par 3.49. 
It is submitted that section 50 (2)(a) does not in any way apply to sale agreements of this nature. The reasons are:

(a) Section 50(2)(a) comes into play only if an agreement is in writing because (i) the parties voluntarily chose to record it in writing, or (ii) the Consumer Protection Act requires it to be recorded in writing. Agreements of sale of land, shares in share-block companies, timeshare and housing interests in retirement schemes are in writing by reason of specific statutory law, not because the parties voluntarily chose to do so or because of any provision in the Consumer Protection Act.

(b) The section applies only to consumer agreements. In terms of the Acts mentioned above a sale agreement signed by the seller only has no legal effect; accordingly it can never purport to establish a relationship in law between the seller and purchaser. The "agreement" is therefore not a consumer agreement under the Consumer Protection Act.

It is furthermore submitted that in the context of property transactions the section is to be applied only to situations where parties orally enter into legally enforceable lease and mandate agreements which they subsequently record in writing for record purposes. What the section conveys is that such agreements are binding and enforceable even if they do not bear the consumer's signature. Conversely, section 50 (2)(a) is not applicable to a lease and mandate agreement which is recorded in writing voluntarily but which neither party regards as enforceable unless it is signed by both of them, or at least by the consumer. An agreement not signed by the consumer in such instances is not a consumer agreement since neither party has had any intention that the unsigned agreement should purport to establish a relationship in law between them.

In the circumstances section 50(2)(a) merely reflects the common law in so far as property transactions are concerned. ${ }^{6}$

\section{CONCLUSION}

Sections 13(1) and 50(2)(a) of the Consumer Protection Act do not pose substantive problems in the context of property transactions. The wording could have been better, but it is not a challenging task to determine how and to what extent these two sections apply to property transactions. However, the position is markedly different in relation to section 14 . The section is badly drafted, making it difficult to determine its scope and application even if applying a purposive interpretation. What it lacks in particular is a definition of a "fixed-term agreement". A revision of the provision is essential.

${ }^{64}$ See Goldblatt v Fremantle 1920 AD 123. 